\title{
$36{ }^{\circ} \mathrm{C}$ ısıtılmış \%10'luk povidon-iyot solüsyonunun sezaryen
}

\section{operasyonlarında hastanın hemodinamiği üzerine etkisi}

\section{Effect of $36{ }^{\circ} \mathrm{C}$ heated $10 \%$ povidone-iodine solutions on patient's hemodynamics in caeserean operations}

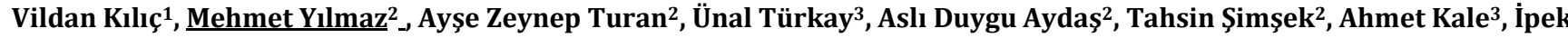 \\ Yakın Düzyol' ${ }^{2}$, Emine Yurt ${ }^{2}$, Hasan Terzi ${ }^{3}$ \\ 1 Uludağ Üniversitesi, Algoloji Kliniği, Bursa, Türkiye \\ 2Sağlık Bilimleri Üniversitesi, Derince Eğitim Ve Araştırma Hastanesi, Anesteziyoloji Ve Reanimasyon Kliniği, Kocaeli, \\ Türkiye \\ 3 Sağlık Bilimleri Üniversitesi, Derince Eğitim Ve Araştırma Hastanesi, Kadın Doğum Kliniği Kliniği, Kocaeli, Türkiye
}

\section{$\ddot{O} Z$}

GİRIŞ ve AMAÇ: Iodophor solusyonları cerrahi müdahale öncesi cilt antisepsisi için yaygin olarak kullanılmaktadır. Enyaygın kullanılan iodophor solusyonu \%10 povidoneiodine'dir (PVI). Sezaryen operasyonlarinda cerrahi-alan antisepsisinin anestezi indüksiyonundan önce yapılması genel anestezi uygulamasıdır. Bu sayede yenidoğan, daha az anestetik ajana maruz kalmaktadır.Bu çalışmada, genel anestezi altında sezaryen operasyonu uygulanan hastalarda farklı sicakliklarda PVI solusyonunun kullanılmasinin hastanın hemodinamisi üzerine etkisini karşılaştırmayı amaçladık.

YÖNTEM ve GEREÇLER: Çalışmaya 178 genel anestezi altında opere edilen sezeryan hastasi dahil edildi. Oda ısisindaki PVI kullanılan hastalar 'Soğuk PVI' grubu (n=93) olarak, EmTherm 3DS(EM-MED) ile $36{ }^{\circ} \mathrm{C}$ isitilan PVI kullanilan hastalar 'Sicak PVI' grubu $(n=85)$ olarak adlandirtld.

BULGULAR: Grubların SKB değerleri karşılaşstırıldığında bazal, indüksiyon, entübasyon, 5. dakika, 10. dakika ölçüm değerleri arasında istatistiksel olarak benzerlik bulundu ( $p>0.05$ ). Ancak PVI ile boyama sonrası SKB değeri Soğuk PVI grubunda istatistiksel olarak anlaml yüksek bulundu $(p=0.040)$. Ayrıca operasyon başlangıç ve bitiş vucut ısıları, oda ısıları karşılaştırıldığında istatistiksel olarak anlamlı fark saptanmadi $(p>0,05)$.

TARTIŞMA ve SONUÇ: Sezeryan operasyonlarında oda ısısında bekletilen (Soğuk) PVI kullanımının hasta hemodinamisi üzerinde etkisinin bulunduğunu ancak anestezi indüksiyonu ile bu etkinin baskılandiğını düşünüyoruz. Bu nedenle hemodinamik olarak instabil hastalarla, hipertansiyon, diabet, koroner kalp hastalığ, kalp yetmezliği gibi ek komorbiditesi olan hastalarda PVI'un $36{ }^{\circ} C^{\prime}$ e isitulmasinin yararlı olabileceği kanaatindeyiz.

Anahtar Kelimeler: \%10 povidone-iodine, sezaryen operasyonu, genel anestezi, hemodinamik değişiklikler

\section{ABSTRACT}

INTRODUCTION: Iodophore solutions are widely used as skin antiseptics prior to surgery. The most frequently used iodophore solution is $10 \%$ povidone-iodine $(P V I)$. Performing surgical-field antisepsis before the induction of anaesthesia in caesarean section operations is a general anaesthetic practice. In this way, the newborn will be exposed to less of the anaesthetic agent. In this study we aimed to compare PVI solution at specified temperatures on heamodynamic changes of the patients who undergo ceserian section under general anesthesia.

METHODS: 178 patients who underwent elective caesarean section under general anaesthesia were included. The group of patients who received PVI at operating room temperatures was named the "Cold PVI" group $(n=93)$, and the group of patients who received PVI heated to $36^{\circ} \mathrm{C}$ was named the "Warm PVI" group $(n=85)$. The heating of PVI was done using EmTherm $3 D S(E M-M E D)$ heater.

RESULTS: Statistically significant similarities were found when the basal, induction, intubation and 5th and 10th minute post-intubation SAP levels between the groups $(p>0.05)$. However, the SAP levels following surgical staining with PVI were found statistically significantly higher in the "Cold PVI" group $(p=0.040)$. At the beginning and ending of the operation body temperatures and room temperatures were similar between the groups.

DISCUSSION AND CONCLUSION: PVI kept at room temperature (Cold PVI) before use in caesarean section operations does seem to affect the patient haemodynamics, but this effect is suppressed by anaesthetic induction. Therefore, we suggest that PVI heated up to $36^{\circ} \mathrm{C}$ may be beneficial in haemodynamically unstable patients and patients who have comorbidities, such as hypertension, diabetes, coronary arterial disease and heart failure.

Keywords: $10 \%$ povidone-iodine, cesarean operation, general anesthesia, hemodynamic changes

İletişim / Correspondence:

Mehmet Yilmaz

Sağlık Bilimleri Üniversitesi, Derince Ĕ̆itim Ve Araştırma Hastanesi, Anesteziyoloji Ve Reanimasyon Kliniği, Kocaeli, Türkiye

E-mail: drmyilmaz33@mynet.com

Başvuru Tarihi: 10.08.2018

Kabul Tarihi: 14.10.2018 


\section{INTRODUCTION}

Iodophore solutions are widely used as skin antiseptics prior to surgery. 1 The most frequently used iodophore solution is $10 \%$ povidone-iodine (PVI).2,3 PVI is usually preserved and used at operating room conditions, meaning it is generally applied at a temperature of $20-24^{\circ} \mathrm{C}$. Several publications indicated that heating these PVI solutions to $40{ }^{\circ} \mathrm{C}$ enhances patient comfort and does not reduce the antiseptic properties.4-6

The rapid induction of anaesthesia is recommended so that newbornsare less affected by the anaesthesia during caesarean operations.7 In addition, performing surgical-field antisepsis before the induction of anaesthesia in caesarean section operations is a general anaesthetic practice. In this way, the newborn will be exposed to less of the anaesthetic agent. However, we hypothesized that the temperature of the PVI solution used in this case may cause hemodynamic changes by stimulating the patient's sympathoadrenal system, because temperature considered as one of the stress factors in the literature. The autonomic sympathetic system, which is stimulated by stress factors such as temperature, causes catecholamine secretions from the adrenal medulla. For this reason, we compared the use of PVI at two different temperatures for surgical field antisepsis before anaesthesia induction in caesarean operations; the hypothesis was that catecholamine may be secreted at different levels at the two different temperatures and thus cause different hemodynamic responses at.8-12

\section{MATERIALS AND METHOD}

Following approval of the local ethics committee, 1,321 patients operated on in the same operating room of the Obstetrics and Gynecology Department of our university hospital between July 2016 and July 2017 were evaluated. Among these, 846 patients preferred regional anaesthesia, and 297 patients underwent urgent surgery and were excluded from the study. Obtaining informed consent, 178 patients received an elective caesarean section under general anaesthesia and were randomized into two groups using the closedenvelope method.
The group of patients who received PVI at operating room temperatures was named the"Cold PVI" group $(n=93)$, and the group of patients who received PVI heated to $36^{\circ} \mathrm{C}$ was named the "Warm PVI" group ( $\mathrm{n}=85$; Figure 1). The heating of PVI was done using EmTherm 3DS(EM-MED) heater.

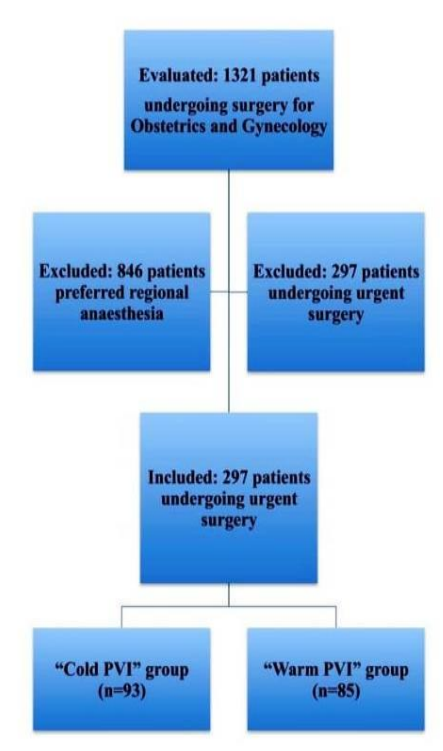

Figure 1. Flowchart

Premedication was not performed prior to the operations. The patients were monitored in terms of standard electrocardiography (ECG), peripheral oxygen saturation ( $\mathrm{SpO} 2)$, non-invasive blood pressure and body temperature. Following a load of $500 \mathrm{ml}$ of a $0.9 \% \mathrm{NaCl}$ solution, a continuous infusion at a rate of $10 \mathrm{ml} / \mathrm{kg} / \mathrm{h}$ was started through a $20 \mathrm{G}$ intravenous cannula inserted on the left hand.

After eight times ventilating the vital capacity of their lungs in the first minute by $100 \%$ oxygen, the patients were given propofol $(2-2.5 \mathrm{mg} / \mathrm{kg})$ and rocuronium bromide $(0.6-1 \mathrm{mg} / \mathrm{kg})$ for anaesthetic induction, and tracheal intubation was performed with a number 6.5-7.0 endotracheal tube (ETT). The anaesthetic was maintained using 1 minimum alveolar concentration (MAC) of sevoflurane and nitrous oxide in $50-100 \%$ oxygen until birth, with 0.5-0.75 MAC sevoflurane, 1 MAC nitrous oxide and opioids following the birth and $1 \mathrm{mg}$ midazolam to prevent awareness. 
The heart rate (HR), $\mathrm{SpO} 2$, systolic arterial pressure (SAP), diastolic arterial pressure (DAP) and mean arterial pressure (MAP) were measured by non-invasive methods once the patients entered the operating room, and these were recorded as basal values. These values were again measured and recorded following surgical cleansing, anaesthetic induction, orotracheal intubation with laryngoscopy, and on the 5th and 10th minutes of intubation. Likewise, the operating room temperatures were recorded at the beginning and at the end of the operations. Surgical site infections that occurred in the first 30 days post-operation were recorded.

\section{RESULTS}

One hundred and seventy-eight patients aged between 18 and 42 years were enrolled in the study. There were no significant differences between the groups in terms of age, body weight, height and rates of wound infection. There was also no statistically significant difference between groups when the body temperatures of the patients and operating room temperatures at the start and end of the operations were compared ( $p>0.05$; Table 1).

\begin{tabular}{|c|l|l|l|}
\hline \multicolumn{3}{|c|}{ Table 1. Demographic data of the groups } \\
\hline & $\begin{array}{l}\text { Cold PVI } \\
(n=93)\end{array}$ & $\begin{array}{l}\text { Warm } \\
\text { PVI } \\
(n=85)\end{array}$ & P \\
\hline Age (Year) & $28.49 \pm 5.71$ & $29.2 \pm 5.32$ & $0.396^{*}$ \\
\hline Weight (kg) & $79.24 \pm 11.27$ & $\begin{array}{l}79.71 \pm 11.2 \\
5\end{array}$ & $0.930^{* *}$ \\
\hline Height (cm) & $162.10 \pm 5.32$ & $\begin{array}{c}162.25 \pm 5.4 \\
5\end{array}$ & $0.942^{* *}$ \\
\hline $\begin{array}{c}\text { Body temperature } \\
\text { begining of } \\
\text { operation }\end{array}$ & $36.58 \pm 0.39$ & $36.54 \pm 0.28$ & $0.385^{* *}$ \\
\hline $\begin{array}{c}\text { Body temperature } \\
\text { end of operation }\end{array}$ & $36.29 \pm 0.41$ & $36.33 \pm 0.33$ & $0.670^{* *}$ \\
\hline $\begin{array}{c}\text { Room temperature } \\
\text { beginning of } \\
\text { operation }\end{array}$ & $20.61 \pm 1.10$ & $20.36 \pm 1.27$ & $0.068^{* *}$ \\
\hline $\begin{array}{c}\text { Room temperature } \\
\text { end of operation }\end{array}$ & $20.70 \pm 1.06$ & $20.44 \pm 1.26$ & $0.051^{* *}$ \\
\hline $\begin{array}{c}\text { Wound site } \\
\text { enfection }\end{array}$ & $0.03 \pm 0.17$ & $0.02 \pm 0.15$ & $0.726^{* *}$ \\
\hline
\end{tabular}

Statistically significant similarities were found when the basal, induction, intubation and 5th and 10th minute post-intubation SAP levels were compared between the groups ( $p>0.05)$.
However, the SAP levels following surgical staining with PVI werefound to be statistically significantly higher in the "Cold PVI" group ( $\mathrm{p}=0.040$; Table 2).

\begin{tabular}{|c|c|c|c|}
\hline & $\begin{array}{l}\text { Cold PVI } \\
(\mathrm{n}=93)\end{array}$ & $\begin{array}{l}\text { WarmPVI } \\
(\mathrm{n}=85)\end{array}$ & $\mathbf{p}$ \\
\hline Basal SAP & $\begin{array}{c}127.25 \pm 14.3 \\
4\end{array}$ & $\begin{array}{c}124.49 \pm 11 \\
94\end{array}$ & $0.364^{*}$ \\
\hline $\begin{array}{c}\text { Surgical cleansing } \\
\text { SAP }\end{array}$ & $\begin{array}{c}130.50 \pm 12.8 \\
2\end{array}$ & $\begin{array}{c}126.67 \pm 11 \\
78\end{array}$ & $0.040^{* *}$ \\
\hline Induction SAP & $\begin{array}{c}116.03 \pm 21.6 \\
6\end{array}$ & $\begin{array}{c}117.56 \pm 14 \\
18\end{array}$ & $0.446^{*}$ \\
\hline Intubation SAP & $\begin{array}{c}139.50 \pm 23.5 \\
0\end{array}$ & $\begin{array}{c}142.50 \pm 22 \\
06\end{array}$ & $0.382^{* *}$ \\
\hline 5. minute SAP & $\begin{array}{c}125.95 \pm 19.3 \\
4\end{array}$ & $\begin{array}{c}123.12 \pm 16 \\
38\end{array}$ & $0.459^{*}$ \\
\hline 10. minute SAP & $\begin{array}{c}117.67 \pm 14.0 \\
1\end{array}$ & $\begin{array}{c}116.29 \pm 15 \\
30\end{array}$ & $0.349^{*}$ \\
\hline \multicolumn{4}{|c|}{$\begin{array}{l}{ }^{*} \text { Independent Samples T test: values are given as mean } \pm \text { standard } \\
\text { deviation } \\
\text { **Mann Whitney U test: values are given as mean } \pm \text { standard } \\
\text { deviation }\end{array}$} \\
\hline
\end{tabular}

All values measured for the comparison of the DAP and MAP levels between the groups were found to be statistically similar ( $p>0.05$; Table 3 and Table 4, respectively), and the same was true for the comparison of the $\mathrm{HR}$ and $\mathrm{SpO} 2$ levels between the groups ( $p>0.05$; Table 5 and Table 6, respectively).

Table 3. DAP data of groups

\begin{tabular}{|l|l|l|l|}
\hline Basal DAP & $\begin{array}{l}\text { Cold PVI } \\
(\mathbf{n = 9 3 )}\end{array}$ & $\begin{array}{l}\text { Warm PVI } \\
(\mathbf{n = 8 5})\end{array}$ & $\mathrm{p}$ \\
\hline $\begin{array}{l}74.92 \pm 10.5 \\
\text { Surgical } \\
\text { Cleansing DAP }\end{array}$ & $\begin{array}{l}76.19 \pm 11.4 \\
5\end{array}$ & $74.84 \pm 9.58$ & $0.478^{*}$ \\
\hline Induction DAP & $67.35 \pm 13.0$ & $68.38 \pm 11.65$ & $0.466^{* *}$ \\
\hline $\begin{array}{l}\text { Intubation } \\
\text { DAP }\end{array}$ & $\begin{array}{l}65.54 \pm 17.9 \\
3\end{array}$ & $86.11 \pm 17.61$ & $0.746^{* *}$ \\
\hline $\begin{array}{l}\text { 5. minute DAP } \\
\text { 10. minute }\end{array}$ & $68.78 \pm 13.1$ & $65.80 \pm 11.30$ & $0.134^{* *}$ \\
\hline $\begin{array}{l}\text { DAP } \\
\text { * Independent Samples T test: values are given as mean } \pm \text { standard } \\
\text { deviation. *Mann Whitney U test: values are given as mean } \pm \\
\text { standard deviation }\end{array}$ & $63.02 \pm 8.84$ & $61.62 \pm 9.81$ & $0.187^{* *}$ \\
\hline
\end{tabular}




\begin{tabular}{|c|c|c|c|}
\hline & $\begin{array}{c}\text { Cold PVI } \\
(n=93)\end{array}$ & $\begin{array}{l}\text { Warm PVI } \\
(\mathbf{n}=\mathbf{8 5})\end{array}$ & \\
\hline Basal MAP & $94.90 \pm 11.05$ & $93.22 \pm 9.63$ & $0.283^{*}$ \\
\hline $\begin{array}{c}\text { Surgical } \\
\text { cleansing MAP }\end{array}$ & $97.10 \pm 11.21$ & $94.40 \pm 8.29$ & $0.067^{*}$ \\
\hline Induction MAP & $86.27 \pm 14.88$ & $88.24 \pm 15.17$ & $0.376^{* *}$ \\
\hline $\begin{array}{l}\text { Intubation } \\
\text { MAP }\end{array}$ & $105.09 \pm 18.73$ & $106.81 \pm 19.13$ & $0.547^{*}$ \\
\hline 5. minute MAP & $91.26 \pm 14.47$ & $87.96 \pm 11.29$ & $0.136^{* *}$ \\
\hline $\begin{array}{l}\text { 10. minute } \\
\text { MAP }\end{array}$ & $84.75 \pm 12.75$ & $83.35 \pm 10.77$ & $0.311^{* *}$ \\
\hline \multicolumn{4}{|c|}{$\begin{array}{l}\text { *Independent Samples } T \text { test: values are given as mean } \pm \text { standard } \\
\text { deviation **Mann Whitney U test: values are given as mean } \pm \\
\text { standard deviation }\end{array}$} \\
\hline
\end{tabular}

\begin{tabular}{|l|l|l|l|}
\hline \multicolumn{4}{|l|}{ Table 5. HR Data Of Groups } \\
\hline & $\begin{array}{l}\text { Cold PVI } \\
\text { (n=93) }\end{array}$ & $\begin{array}{l}\text { Warm PVI } \\
(\mathbf{n = 8 5})\end{array}$ & \\
\hline Basal HR & $95.82 \pm 14.88$ & $92.56 \pm 14.37$ & $0.139^{*}$ \\
\hline $\begin{array}{l}\text { Surgical } \\
\text { cleansing HR }\end{array}$ & $96.89 \pm 13.63$ & $96.03 \pm 14.87$ & $0.689^{*}$ \\
\hline Induction HR & $105.40 \pm 17.7$ & $102.09 \pm 17.67$ & $0.362^{* *}$ \\
\hline Intubation HR & $\begin{array}{l}117.67 \pm 16.7 \\
9\end{array}$ & $118.04 \pm 15.64$ & $0.880^{*}$ \\
\hline $\begin{array}{l}\text { 5. minute HR } \\
\text { 10. minute HR }\end{array}$ & $96.96 \pm 16.79$ & $99.84 \pm 14.60$ & $0.227^{*}$ \\
\hline $\begin{array}{l}\text { *Independent Samples T test: values are given as mean } \pm \text { standard } \\
\text { deviation }{ }^{* *} \text { Mann Whitney U test: values are given as mean } \pm \\
\text { standard deviation }\end{array}$ & \multicolumn{4}{|l}{} \\
\hline
\end{tabular}

\begin{tabular}{|l|l|l|l|}
\hline \multicolumn{4}{|l|}{ Table 6. SPO2 Data of Groups } \\
\hline & $\begin{array}{l}\text { Cold PVI } \\
(\mathbf{n}=93)\end{array}$ & $\begin{array}{l}\text { Warm PVI } \\
(\mathbf{n}=\mathbf{8 5})\end{array}$ & $\mathbf{p}$ \\
\hline Basal SPO2 & $98.76 \pm 1.03$ & $98.63 \pm 1.35$ & ${ }^{*} 0.677$ \\
\hline $\begin{array}{l}\text { Surgical } \\
\text { Cleansing } \\
\text { SPO2 }\end{array}$ & $99.17 \pm 0.90$ & $99.22 \pm 0.87$ & $* 0.752$ \\
\hline $\begin{array}{l}\text { Induction SPO2 } \\
\text { Intubation } \\
\text { SPO2 }\end{array}$ & $99.54 \pm 0.68$ & $99.56 \pm 0.68$ & ${ }^{*} 0.971$ \\
\hline $\begin{array}{l}\text { 5. minute SPO2 } \\
99.35 \pm 0.96\end{array}$ & $99.31 \pm 1.02$ & $* 0.949$ \\
\hline $\begin{array}{l}\text { 10. minute } \\
\text { SPO2 }\end{array}$ & $99.03 \pm 1.03$ & $98.95 \pm 0.96$ & $* 0.410$ \\
\hline "Mann Whitney U test: values are given as mean \pm standard deviation \\
\hline
\end{tabular}

The changes in both of the groups were similar in terms of the evaluation of the intra-group haemodynamic parameters. Statistically significant similarities were found between the basal levels and the levels following the surgical staining in terms of the SAP (Figure 2), DAP (Figure 3), MAP (Figure 4) and HR (Figure 5). Statistically significant differences were found forthe other measurements.
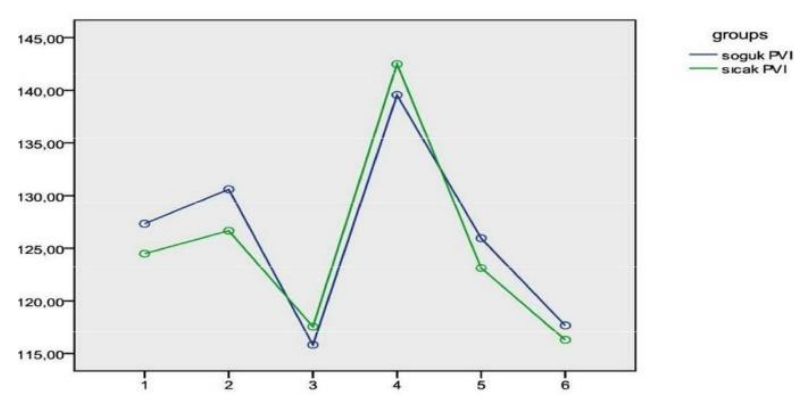

Figure 2. SAP data of groups

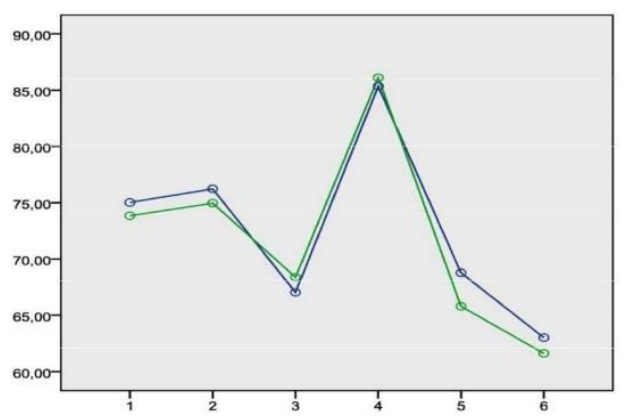

Figure 3. DAP data of groups

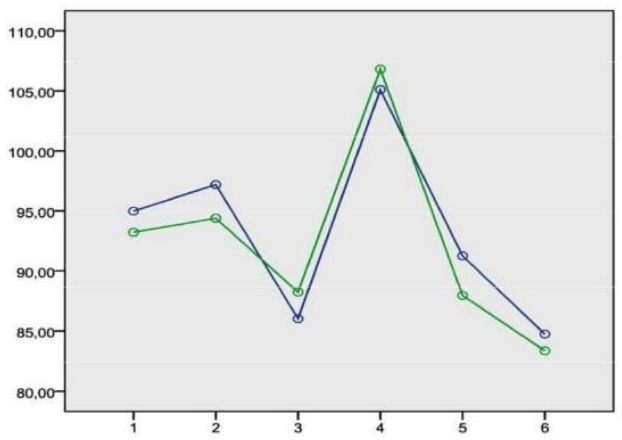

Figure 4. MAP data of groups 


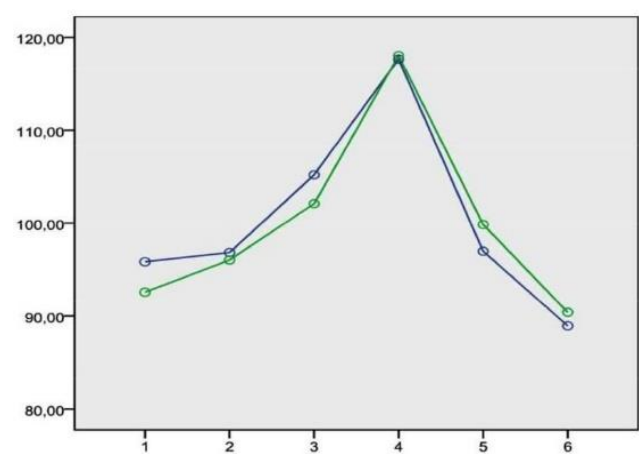

Figure 5. HR data of groups

\section{DISCUSSION}

Laryngoscopy and tracheal intubation may cause a hemodynamic responsesuch as tachycardia and hypertension.This hemodynamic change cancause serious vital complications.13-15 There are clinical trials showing that the activation of the autonomic sympathetic system causes catecholamine secretions, and these catecholamines play a role in the formation of this hemodynamic response.16,17 Similarly, the surgical procedure itself can initiate the stress response of the hypothalamic-pituitaryadrenal axis. In addition to the stimulation of cytokine production, neural stimulation from the surgical site plays a role in the development of the stress response during surgery.18 For this reason, we believe that surgical field antisepsis before anaesthesia induction could lead to the stress response. Deeper anaesthesia, opioids and vasodilators can prevent this sympathoadrenal response, and alpha and beta adrenergic blockers are widely used to prevent the hemodynamic response to laryngoscopy and endotracheal intubation.19-22 However, the use of drugs such as opioids and other alternatives in special groups of patients, such as pregnant women, are limited because of transplacental drug transfer, which can cause undesirable effects for the baby.23,24

The haemodynamic response caused by laryngoscopy and endotracheal intubation is still a problem for pregnant patients. We hypothesized that using askin antiseptic before anaesthesia induction, in order to reduce the anaesthetic exposure for the newborn, could increase the haemodynamic response to laryngoscopy and endotracheal intubation.
Temperature has also been considered as one of the stress factors in the literature. The autonomic sympathetic system that is induced by stress causes the discharge of catecholamines from the adrenal medulla.8-12 Therefore, we hypothesized that the use of PVI at two different temperatures for caesarean section operations in which the surgical site cleaning was applied before anaesthetic induction couldresult in different levels of catecholamine discharge and different levels of a haemodynamic response. In our study, the SAP levels were found to be statistically significantly higher in the "Cold PVI" group following the surgical cleansing with PVI $(\mathrm{p}=0.040)$, although the base SAP levels were statistically similar between the two groups ( $p>0.05$; Table 2$)$. We supposed that PVI heated to a normal body temperature $\left(36^{\circ} \mathrm{C}\right)$ wouldnot induce the autonomous sympathetic system, but PVI kept at room temperature (Cold PVI) induced the autonomous sympathetic system, resulting in catecholamine discharge.

Increased patient comfort with the use of PVI heated to $40^{\circ} \mathrm{C}$ was mentioned in the literature. It was also mentioned in these studies that no decrease in the antibacterial effect of PVI occurred through heating.4-6 This is likely true, since the surgical site infection rates were found to be statistically similar among the groups in our study ( $\mathrm{p}=0.726$; Table 1). We interpreted this to mean that heating the PVI to $36^{\circ} \mathrm{C}$ had no effect on the postoperative wound site infection rate.

Instead of serum catecholamine levels, haemodynamic changes were used as the evaluation method for the effects of PVI at different temperatures, which forms the major limitation of our study.

In conclusion, it seems that PVI heated to $36^{\circ} \mathrm{C}$ does not affect the body temperature or the incidence rates for postoperative surgical site infections. Moreover, PVI kept at room temperature (Cold PVI) before use in caesarean section operations does seem to affect the patient haemodynamics, but this effect is suppressed by anaesthetic induction. Therefore, we suggest that PVI heated up to $36^{\circ} \mathrm{C}$ may be beneficial in haemodynamically unstable patients and patients who have comorbidities, such as hypertension, diabetes, coronary arterial disease and heart failure. 


\section{REFERENCES}

1. Gottardi, W. Iodine and iodine compounds. in Disinfection, Sterilization and Preservation (ed. Block, S. S.) (Lippincott Williams Willkins, 2001).pp.159-183.

2. B. Carroll, J. Kevsin, and I. Steinmen, "The mode of action of iodine on infectious agents," J. Newark Beth Isr. Hosp, 1955.

3. K. Capriotti and J. Capriotti, "Topical iodophor preparations: chemistry, microbiology, and clinical utility," Dermatol. Online J., 2012.

4. N. Hulse and A. Paul, "Warm povidone-iodine for surgical skin preparation.," Ann. R. Coll. Surg., 2005.

5. M. Leung, K. Bishop, and M. Monga, "The effect of temperature on bactericidal properties of $10 \%$ povidone-iodine solution," Am. J. Obstet., 2002.

6. T. Maloney and B. O'Neill, "Stability of povidone-iodine antiseptic solution stored at 37 degrees C.," Med. J. Aust., 1986.

7. R. D. Miller, Miller's anesthesia. Churchill Livingstone/Elsevier, 2010.

8. H. Selye, The story of the adaptation syndrome. Montreal: Medical Publishers, 1952.

9. H. SELYE, "Stress and disease.," Science, vol. 122, no. 3171, pp. 625-31, Oct. 1955.

10.P. Csermely, Stress of Life : From Molecules to Man. New York Academy of Sciences, 1998.

11.E. Yurdakoş, Lecture Notes on Neurophysiology. Nobel Tip Kitapları, 2001.

12.G. Menteş and B. Ersöz, Harper'ın Biyokimyası. İstanbul , 1993.

13.Y. Hamaya and S. Dohi, "Differences in cardiovascular response to airway stimulation at different sites and blockade of the responses by lidocaine," Anesthesiology, vol. 93, pp. 95- 103, 2000.

14.V. Collins, "Lea-Febiger Endotracheal Anesthesia Complications. Collins VJ. Editor Principles of Anesthesia; 3. th edition, Philadelphia; 1993; Vol 1

15.N. D. Edwards, A. M. Alford, P. M. Dobson, J. E. Peacock, and C. S. Reilly, "Myocardial ischaemia during tracheal intubation and extubation.," Br. J. Anaesth 1994, vol. 73, no. 4, pp. 537-9.
16.A. L. Kovac, "Controlling the hemodynamic response to laryngoscopy and endotracheal intubation.," J. Clin. Anesth., vol. 8, no. 1, pp. 6379, Feb. 1996.

17.D. R. Derbyshire, A. Chmielewski, D. Fell, M. Vater, K. Achola, and G. Smith, "Plasma catecholamine responses to tracheal intubation.," Br. J. Anaesth., vol. 55, no. 9, pp. 855-60, Sep. 1983.

18.Naito, Y., Tamai, S., Shingu, K., Shindo, K., Matsui, T., Segawa, H., ... \& Mori, K. (1992). Responses of plasma adrenocorticotropic hormone, cortisol, and cytokines during and after upper abdominal surgery. Anesthesiology, 77(3), 426431.

19.Z. Kayhan, "Endotrakeal Entübasyon," in Klinik Anestezi Genişletilmiş 3. Baskı, 3.th., İstanbul, 2004, pp. 243-306.

20.D. Memiş, A. Turan, B. Karamanlioğlu, N. Süt, and Z. Pamukçu, "The use of magnesium sulfate to prevent pain on injection of propofol.," Anesth. Analg., vol. 95, no. 3, p. 606-8, table of contents, Sep. 2002.

21.W. B. Ashton, M. F. James, P. Janicki, and P. C. Uys, "Attenuation of the pressor response to tracheal intubation by magnesium sulphate with and without alfentanil in hypertensive proteinuric patients undergoing caesarean section.," Br. J. Anaesth., vol. 67, no. 6, pp. 741-7, Dec. 1991.

22.S. M. Helfman, M. I. Gold, E. A. DeLisser, and C. A. Herrington, "Which drug prevents tachycardia and hypertension associated with tracheal intubation: lidocaine, fentanyl, or esmolol?," Anesth. Analg., vol. 72, no. 4, pp. 4826, Apr. 1991.

23.İ. Kocamanoğlu, B. Sarıhasan, B. Şener, T. Ayla, H. Şahinoğlu, and T. Sunter, "Methods And Complications Of Anesthesia In Cesarean/Section Operations: Retrospective Evaluations Of 3552," Turkiye Klin. J. Med. Sci., vol. 25, no. 6, pp. 810816, 2005.

24.İ. Büyükkömürcü, G. Aslan, M. Otuzbir, Ö. Karakaya, A. Boztepe, and Z. Arıkan, "A Comparision of The Maternal And Neonatal Effects Of Remifentanıl Used Durıng Induction For General Anaesthesı," J. Kartal Train. Res. Hosp., vol. 12, pp. 59-63, 2001. 